\title{
Erratum to: Sequence Diversity Diagram for comparative analysis of multiple sequence alignments
}

Ryo Sakai ${ }^{1,2^{*}}$, Jan Aerts ${ }^{1,2}$

From 3rd IEEE Symposium on Biological Data Visualization

Atlanta, GA, USA. 13-14 October 2013

\section{Correction}

After publication of this Research Article [1], we noted that figure 2 and 3 had been swapped round. The correct images can be seen below:

This error was introduced during the final production process by the publisher and BioMed Central apologises for any inconvenience caused.
Figure 1 for the Research Article [1] can also be seen below for reference:

\section{Pre-publication history}

The pre-publication history for this paper can be accessed here: http://www.biomedcentral.com/1753$6561 / 8 / \mathrm{S} 2 / \mathrm{S} 9$.

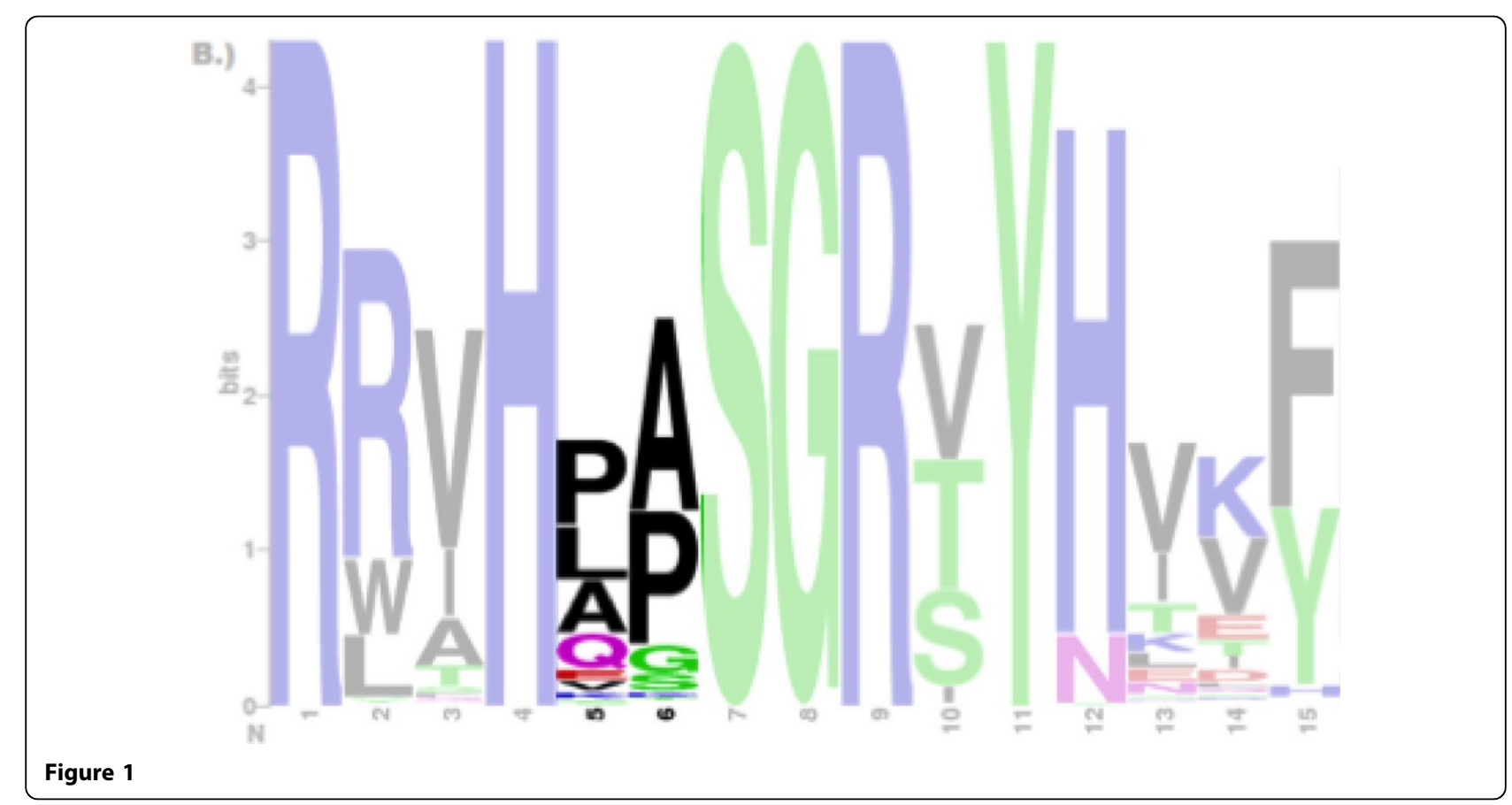

\footnotetext{
* Correspondence: ryo.sakai@esat.kuleuven.be

'Department of Electrical Engineering (ESAT) STADIUS Center for Dynamical Systems, Signal Processing and Data Analytics, KU Leuven, Kasteelpark Arenberg 10, 3001 Leuven, Belgium

Full list of author information is available at the end of the article
}

(c) 2014 Sakai and Aerts; licensee BioMed Central Ltd. This is an Open Access article distributed under the terms of the Creative Commons Attribution License (http://creativecommons.org/licenses/by/4.0), which permits unrestricted use, distribution, and 

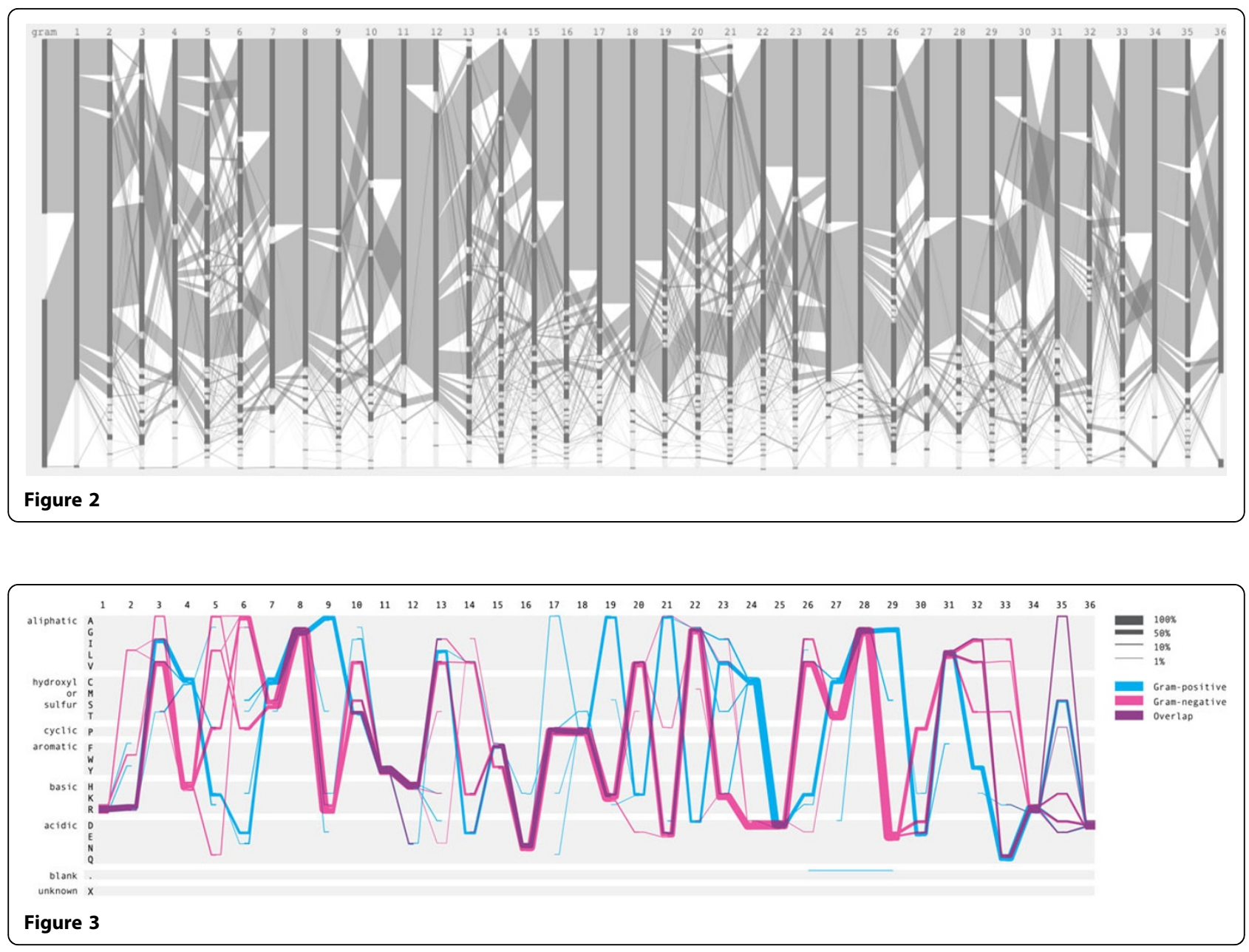

\section{Declarations}

This article has been published as part of BMC Proceedings Volume 8 Supplement 2, 2014: Proceedings of the 3rd Annual Symposium on Biological Data Visualization: Data Analysis and Redesign Contests. The full contents of the supplement are available online at http://www. biomedcentral.com/bmcproc/supplements/8/S2.

\section{Authors' details}

'Department of Electrical Engineering (ESAT) STADIUS Center for Dynamical Systems, Signal Processing and Data Analytics, KU Leuven, Kasteelpark Arenberg 10, 3001 Leuven, Belgium. ${ }^{2}$ Minds Medical IT, Leuven, Belgium.

\section{Published: 17 December 2014}

\section{Reference}

1. Sakai R, Aerts J: Sequence Diversity Diagram for comparative analysis of multiple sequence alignments. BMC Proceedings 2014, 8(2):S9.

doi:10.1186/1753-6561-8-S2-S10

Cite this article as: Sakai and Aerts: Erratum to: Sequence Diversity Diagram for comparative analysis of multiple sequence alignments. BMC Proceedings 2014 8(Suppl 2):S10.

\section{Submit your next manuscript to BioMed Central and take full advantage of:}

- Convenient online submission

- Thorough peer review

- No space constraints or color figure charges

- Immediate publication on acceptance

- Inclusion in PubMed, CAS, Scopus and Google Scholar

- Research which is freely available for redistribution

Submit your manuscript at www.biomedcentral.com/submit 